\author{
M.A. Pshembayev ${ }^{1, *}$, A.A. Kudysheva ${ }^{2}$ \\ ${ }^{1,2}$ Toraighyrov University, Pavlodar, Kazakhstan \\ (E-mail: pshembaev_murat@bk.ru) \\ ORCID: ${ }^{1}$ 0000-0002-7256-7220, ${ }^{2} 0000-0002-3410-2676$
}

\title{
Student Leadership Development as a new trend of Higher Education in Kazakhstan
}

\begin{abstract}
In this paper, some specific issues of student leadership development in Kazakhstan universities were considered. The authors draw attention to the fact that leadership development is now becoming an integral part of the undergraduate and graduate educational programs. This paper reviews different leadership approaches and theories to analyze the question of student leadership development and gives the historical classification of leadership studies in the USA. Likewise, in the paper, a brief review was given to the experience of Toraighyrov University in implementing a specific leadership development program, which is designed with taking into account the cultural, professional and educational uniqueness of the region. The researchers of the article offer another alternative way for leadership skills development - creation of a leadership school in the form of non-government organization. Based on the theoretical research conducted by the authors, the main ways of formation of leadership qualities and necessary skills due to several objective and subjective circumstances were identified.
\end{abstract}

Keywords: leadership, student, leadership development programs, leadership qualities, higher education, leadership theories, Toraighyrov University, Kazakhstan Republic.

\section{Introduction}

Nowadays, Kazakhstan Republic's High Education faces a multitude of complex social and professional issues. Currently, we are witnessing a shift from management development towards leadership development, not only in the university administration but also in the educational process. The system of higher education is aimed at training and preparing a professional, who can offer innovative ideas and lead others around him through gaining organizational skills and having an internal desire for social activity.

Leadership qualities are one of the leading characteristics of the personality of a modern person. The formation of these qualities at different stages of ontogenesis is an essential task of pedagogical psychology. The personal qualities of a leader, which were inherent in children as early as the school period of life, can and should receive impulses for further formation at subsequent stages of life. This is especially true for such a period, designated as student age.

Being the personnel resource of society, young people studying at a university, like no one else, strive to prove themselves most fully, to form the most demanded social and professional competencies for the current moment in history. It is important that for this age, the presence of adequately developed leadership qualities is not only a need for the development of the individual as such but also its development in the context of the emerging socio-political and economic transformations of modern society. In the conditions of continuous change of all aspects of society, as ever, young, knowledgeable, energetic, initiative leaders who can rally like-minded people around themselves, clearly and formulate before them urgently, immediate and promising tasks, support difficulties in minutes and reach new heights.

Leadership development is now becoming an integral part of the undergraduate and graduate educational programs, with courses and activities running the gamut from curricular classes offered by a variety of academic disciplines (the leading role is given to such disciplines as leadership and organizational psychology, education, management, and business) to co-curricular programs offered by various student affairs offices (such as leadership organizations, volunteer programs, etc.). This substantial matter has spurred a plethora of research made in leadership development in different spheres of human beings, along with surveys and instruments to measure and assess skills related to various leadership initiatives.

However, in practice, among university students, the proportion of students who are sufficiently inert, amorphous, do not have any expressed abilities and do not seek to express themselves, to achieve prestigious

*Corresponding author's e-mail: pshembaev_murat@bk.ru 
social status by their efforts is still quite significant. Such apathetic manifestations impede the processes of their social adaptation and professional development. Because of this, in the school and after school periods of life, a certain organizational and psychological-pedagogical activity is required to help young people in developing their leadership aspirations, and, consequently, competitiveness and success in all social fields.

The problem of developing leadership aspirations among university students is at the crossroads of several areas of research in psychological science, which have been intensively developed in the last decade.

Most universities and colleges in Kazakhstan in the process of student leadership development are directed to the experiences of the USA and European universities. Nevertheless, Kazakhstan educational system is a part of the Bologna Process, most universities have chosen American Universities' leadership development models. Many of the leadership development programs in American Universities are designed based upon studies and models that were developed for managers in business and public-sector organizations [1]. Still, it is a doubt question, because such models are substantial for education systems which are completely different from the environment in which industries and corporations cooperate.

Toraighyrov University tries to create and implement a leadership development program, suitable for the educational and cultural environment of the University mentioned above.

\section{Experimental}

Among a big number of leadership theories, Action -Centered Leadership model is the most appropriate for Kazakhstan culture due to its historical background, people mentality and simplicity of this theory.

This model demonstrates leadership perception by Kazakhstan leaders through task-, team- and individual orientation. Kazakhstan leaders are task and team oriented rather than individual oriented because historically Kazakh people were developing and growing in collectivistic culture [198], even before Soviet Union period and during this time (Soviet), task management and strict execution of task were deeply inculcated. As a result, there is a low attention given to the individual development within a team and thus, there is a tendency of low investment in young generation of Kazakhstan.

University students face unprecedented pressure to graduate ready to confront an employment and management environment churned by consistent advances in globalization, technology, and diversity in the workforce [1]. The soft skills are put to the first place in the order of most required personal qualities and skills by employees for post-secondary institutions. As a result, most universities and colleges have responded by adding «soft skills» such as communication, leadership, and team management within their criteria for quality education [2]. The National Association for Colleges and Employers state such skills as «leadership,» «problem-solving skills,» and «ability to work in a team» as skills to develop in college more necessary than technical training [3].

To analyze the question of student leadership development the definition for key terms should be given. First of all, the definitions of leadership researches and approaches as a broadening concept will be provided from various sources both scholarly and legitimate. Leadership has long captured the interest of not only academics but also practitioners from different spheres.

Current leadership theories recognize a shift from simple dynamic leadership model (how a leader behaves and execute in collaboration with followers) to the influence of the leaders character on others (who leaders are and how they maximize this self-awareness to lead other) This development of leadership theories from the locus of the individual to a mutual and social relationship between leader and the follower has influenced a shift in the leadership development from skill and knowledge competence to the collaborative and relational capacities [4].

There is still no general agreement among scientists and in the literature on the definition of leadership. The literature review allows us to distinguish the following approaches and theories on leadership and leadership development can be classified as follows:

1. Personality Era: Great Man Period (Bowden, 1927; Clatyle, 1841); Trait Period (Bingham, 1927);

2. Influence Era: Five Bases of Power Approach (French and Raven, 1959); Leaders Dominance Approach (Scheck, 1928);

3. Behavioral Era: Reinforced Change Theory (Bass, 1960); Michigan State Studies (Likert, 1961); Managerial Grid Model (Blake and Moulton, 1964); Action Theory of Leadership (Argyris, 1976); Theories $\mathrm{X}$ and $\mathrm{Y}$ (McGregor, 1960, 1966);

4. Situational Era: Environmental Approach (Hook, 1943); Open-System Model (Katz and Kahn, 1978); Role Attainment Theory (Stogdill, 1959); Leader Role Theory (Homans, 19959); 
5. Contingency Era: Contingency Theory (Friedler, 1964); Path-Goal Theory (Evans, 1970; House, 1971); Situational Theory (Hersey and Blanchard, 1969, 1977); Multiple Linkage Model (Yulk, 1971)

6. Transactional Era: Leader-Member Exchange Theory (Dansereua, Graen and Haga, 1975); Emergent Leadership (Hollander, 1958); Social Exchange Theory (Hollander, 1979; Jacobs, 1970);

7. Cultural Era: Theory Z (Ouch and Jaeger, 1978); Self-Leadership (Manz and Sims, 1987)

8. Transformational Era: Transformational Leadership Theory (Burns, 1978); SFP Leader Theory (Field, 1989; Eden, 1984); Performance Beyond Expectation Approaches (Bass, 1985)

On the bases of academic literature analyses «leadership can be defined as a special psychological formation that stimulates and orientates a person's activity; it is an individual's focus on achieving high results in a certain area of social interaction within and with group members and followers.

Today's leadership development efforts are largely focused on developing two types of leadership: transactional and transformational. Modern Leadership Theories are identified according to different levels of relationship between leaders and followers and may be categorized as transactional or transformational.

Transactional leaders are those who exchange tangible rewards or benefits for the work and loyalty of followers. In contrast, transformational leaders are those who use power and influence to engage with followers, focus on higher-order intrinsic needs, motivate followers by highlighting the value of the specific outcomes and inspire new ways in which those outcomes may be achieved [5].

\section{Results and Discussion}

Many Kazakh and Russian educators and scientists distinguish student youth, a period of enrollment to the post-secondary institutions as the most sensitive and productive period for the development of leadership qualities.

The specific features of this period can be characterized by the transition from vocational training to a new level of personal development known as professional. Enrolment into the university usually is characterized by immersion of students into the campus life and educational process, creating favorable conditions for developing leadership qualities and the formation of important skills.

The period of study at the university is a sensitive period for the formation of leadership aspirations of students due to several objective and subjective circumstances. The objective circumstances conducive to the formation of leadership aspirations include the special responsibility imposed by society on the student as a future specialist and socially active citizen, as well as a significant proportion of the independence delegated to him by the subjects of guardianship. Subjective circumstances include the maturity of all the student's mental functions, his wide knowledge, and the experience of building social interaction.

Currently, Toraighyrov University (my alma mater) is developing a specific leadership development program. The program is designed with taking into account the cultural, professional and educational uniqueness of the region. The leadership development program consists of three main directions:

1. Curricular classes (offered by such educational minors as organizational psychology and management)

2. Co-curricular programs offered by various student affair offices (such as volunteer organizations, community service centers, student communities, student government, etc)

3. Start-up academy (student organization supporting student startups, motivating them to create accumulate fresh ideas and realize them)

Above mentioned three structural divisions of leadership program are directed to develop and form necessary skills and qualities. For example, curricular classes offer training which aimed to develop «soft skills» such as communication and organization skills, public speaking skills, emotional intelligence, and others.

Leadership aspirations as special psychological education, stimulating and orienting human activity, are a form of the orientation of his personality to achieve high results «in a certain area of social interaction, in a certain subject area or problem situation. A necessary condition for leadership is to achieve these results as part of a group that recognizes the dominance of a leader for a more or less extended period, autonomous or linked to any life circumstances. The analysis of the phenomenon made it possible to identify three main components in the structure of leadership aspirations: value-semantic components, motivational and behavioral. The value-semantic component of leadership aspirations characterizes the field of values with which leadership is associated with the subject. The motivational component of leadership aspirations characterizes 
the field of motives of the subject's appeal to leadership behavior. The behavioral component of leadership aspirations characterizes the degree of activity of the subject in the implementation of leadership behavior.

Young people, both leaders and non-leaders, would like to have the power and influence other people as well as further develop their organizational skills. Moreover, being money and career oriented, youth is ready to get more knowledge and skills to meet employers' requirements. However, due to low communication with both university and employer, the young people have to develop these skills during job experience. This slows down the process of acquiring leadership skills and career development. Thus, for leadership skills development, the researcher is offering another alternative of creation of a leadership school in the form of non-government organization.

The Leadership School will help both employees and Kazakhstani youth to advance the existing knowledge and skills and transform young generation from people with specific knowledge into perspective potential employees with universal professional skills, certain sense of purpose, values and characteristics.

The aims of the leadership school correspond to the main objective of the development of high professionals in Kazakhstan, which is fulfilling the gap of well developed leadership skills. The basic idea of leadership school is that it focuses mainly on practical universal skills development, such as communication, negotiation, analytical, critical thinking and other skills rather than providing theoretical background in certain areas. Graduates from this school are to be characterized with strong business skills, they will create a professional society in Kazakhstan and thus, fulfill the leadership skills gap and will be able to realize the set by President of Kazakhstan Strategy «Kazakhstan-2050». These young people will be more confident and in consistence with labor requirement.

In order to develop prospective leaders, the interested parties (graduates, businesses and government) should consider the involvement in the value-based leadership. This type of leadership implies foundation in the form of behavioral and attitude values, which consist of human, nation and country values, such as seniority, respect, learning, achievement, family and diversity. Leaders that follow values philosophy are team and individual oriented people. That is why, it is important for Kazakhstan to further develop all three Adair's areas in balance, because at present, Kazakhstan people are more task-oriented due to historical aspects, present Government tendencies and low involvement in team and individual development.

On the bases of experience and current situation in the Higher Education in Kazakhstan, leadership development should be integrated into the curricular and co-curricular of educational programs through such spheres as an academic sphere (implementing special minor programs), extra-curricular sphere (student affairs and student alliance), and entrepreneurial sphere (student startup).

\section{Conclusion}

There is still no consensus among scholars and academicians about defining such a complex notion as - leadership. Based on the analyses of academic literature «leadership can be defined as a special psychological formation that stimulates and orientates a person's activity; it is an individual's focus on achieving high results in a certain area of social interaction within and with group members and followers. The period of enrollment into universities and colleges is a sensitive period for the formation of leadership qualities and necessary skills due to several objective and subjective circumstances. The objective circumstances are the specific responsibility imposed on the student as a future professional, as well as a new sense of independence delegated to him by his parents or legal guardians. The subjective circumstances are the maturity of a student's mental functions and process, his wide knowledge, and experience in creating social links and interactions.

\section{References}

1 Freeman, F., Knott, K., \& Schwartz, M. (1994). Leadership Education 1994-1995: A Sourcebook; Center for Creative Leadership: Greensboro, NC, USA. Retrieved from https://search.proquest.com/openview/96751dfcd12b4d8eace7d42c163c6918/1? pqorigsite $=$ gscholar\&cbl $=36693$ [Google Scholar $]$.

2 Altbach, P.G. (2013). Globalization and forces for change in higher education. The international imperative in higher education. (pp. 7-10). Rotterdam, The Netherlands: SensePublishers. doi.org/10.1007/978-94-6209-338-6_2

3 National Association of Colleges and Employers. (2013). Job outlook 2013. Bethlehem, PA: National Association of Colleges and Employers.

4 Rosh, David; Ogolsky, Brian; Stephens, Clinton. (Nov 2017). Trajectories of Student Leadership Development Through Training: An Analysis by Gender, Race, and Prior Exposure. Journal of College Student Development, 58 1184-1200. DOI:10.1353/csd.2017.0093 Retrieved from https://muse.jhu.edu/article/678953 
5 John, C, Azusa (2012). The effect of a strength-oriented approach to the leadership development on the psychological capital and authentic leadership capacities of leaders in faith-based higher institutions (Doctoral dissertation) Available form ProQuest Dissertations and Thesis Database. (UMI NO. 3548564)

6 Kezar, A.J. \& Eckel, P.D. (2016). Meeting todays governance challenges: A synthesis of the literature and examination of the future agenda for scholarship. The journal for Higher Education, 75, 371-399. Retrieved from https://eric.ed.gov/? id=EJ704974

\title{
М.А. Пшембаев, А.А. Кудышева \\ Студенттік көшбасшылықты дамыту Қазақстанның жоғары білім берудегі жаңа үрдісі ретінде
}

\begin{abstract}
Мақалада қазақстандық жоғары оқу орындарында студенттік көшбасшылықты дамытудың кейбір нақты мәселелері зерттелген. Авторлар қазіргі таңда көшбасшылықты дамыту бакалавриат пен магистратураның білім беру бағдарламаларының ажырамас бөлігіне айналатынына назар аударған. Сонымен қатар студенттердің көшбасшылық қасиеттерін дамыту мәселесін талдау үшін көшбасшылықтың әртүрлі тәсілдері мен теориялары қарастырылған және АҚШ-та көшбасшылық зерттеулердің тарихи жіктелуі келтірілген. Мақалада өңірдің мәдени, кәсіби және білім беру бірегейлігін ескере отырып әзірленген, көшбасшылықты дамытудың нақты бағдарламасын жүзеге асыру бойынша С. Торайғыров атындағы Павлодар университетінің тәжірибесіне қысқаша шолу жасалған. Мақала авторлары сонымен қатар көшбасшылық қабілеттерді дамытудың тағы бір балама әдісін ұсынған - үкіметтік емес ұйым түрінде көшбасшылық мектебін құру. Теориялық зерттеулер негізінде белгілі бір объективті және субъективті жағдайларға байланысты көшбасшылық қасиеттер мен қажетті дағдыларды қалыптастырудың негізгі жолдары анықталды.
\end{abstract}

Кілт сөздер: көшбасшылық, көшбасшылықты дамыту бағдарламалары, көшбасшылық қасиеттер, жоғары білім, көшбасшылық теориясы, Қазақстан Республикасы.

\section{М.А. Пшембаев, А.А. Кудышева \\ Развитие студенческого лидерства как новая тенденция в высшем образовании Казахстана}

\begin{abstract}
В статье рассмотрены некоторые конкретные вопросы развития студенческого лидерства в казахстанских вузах. Авторы обращают внимание на тот факт, что развитие лидерства в настоящее время становится неотъемлемой частью образовательных программ бакалавриата и магистратуры. Авторами изучены различные подходы и теории лидерства для анализа вопроса о развитии лидерских качеств у студентов и приведена историческая классификация исследований лидерства в США. Кроме того, дан краткий обзор опыта Павлодарского университета имени С. Торайгырова по реализации конкретной Программы развития лидерства, которая разработана с учетом культурной, профессиональной и образовательной уникальности региона. Кроме того, предложен еще один альтернативный путь развития лидерских навыков - создание школы лидерства в форме неправительственной организации. На основании теоретических исследований, определены основные пути формирования лидерских качеств и необходимых навыков в силу определенных объективных и субъективных обстоятельств.
\end{abstract}

Ключевые слова: лидерство, программы развития лидерства, лидерские качества, высшее образование, теории лидерства, Республика Казахстан.

\section{References}

1 Freeman, F., Knott, K., \& Schwartz, M. (1994). Leadership Education 1994-1995: A Sourcebook; Center for Creative Leadership: Greensboro, NC, USA. Retrieved from https://search.proquest.com/openview/96751dfcd12b4d8eace7d42c163c6918/1? pqorigsite $=$ gscholar\&cbl $=36693$ [Google Scholar]

2 Altbach, P.G. (2013). Globalization and forces for change in higher education. The international imperative in higher education. (pp. 7-10). Rotterdam, The Netherlands: SensePublishers. doi.org/10.1007/978-94-6209-338-6_2

3 National Association of Colleges and Employers. (2013). Job outlook 2013. Bethlehem, PA: National Association of Colleges and Employers.

4 Rosh, David; Ogolsky, Brian \& Stephens, Clinton. (Nov 2017). Trajectories of Student Leadership Development Through Training: An Analysis by Gender, Race, and Prior Exposure. Journal of College Student Development, 58 1184-1200. DOI:10.1353/csd.2017.0093. Retrieved from https://muse.jhu.edu/article/678953 
5 John, C, Azusa (2012) The effect of a strength-oriented approach to the leadership development on the psychological capital and authentic leadership capacities of leaders in faith-based higher institutions (Doctoral dissertation) Available form ProQuest Dissertations and Thesis Database. (UMI NO. 3548564)

6 Kezar, A.J. and Eckel, P.D.(2016) Meeting todays governance challenges: A synthesis of the literature and examination of the future agenda for scholarship. The journal for Higher Education, 75, 371-399. Retrieved from https://eric.ed.gov/? id=EJ704974 